\title{
Effect of ovarian hormones on promotion of bactericidal activity by uterine secretions of ovariectomized mares
}

\author{
E. D. Watson, C. R. Stokes, J. S. E. David* and F. J. Bourne \\ Departments of Veterinary Medicine and ${ }^{*}$ Veterinary Surgery, University of Bristol Veterinary \\ School, Langford House, Langford, Bristol BS18 7DU, U.K.
}

\begin{abstract}
Summary. The bactericidal and phagocytic activities of blood neutrophils suspended in uterine washings and the mobilization of neutrophils into the uterine lumen were studied in ovariectomized mares receiving oestradiol benzoate $(\mathrm{N}=4)$, progesterone $(\mathrm{N}=4)$ or oily vehicle $(\mathrm{N}=4)$. Uterine lavage was performed sequentially up to $144 \mathrm{~h}$ after induction of endometritis by intrauterine infusion of glycogen $(1 \%)$. There was no significant difference between the 3 groups in speed of mobilization of neutrophils into the uterus in the first $6 \mathrm{~h}$ after infusion but there were significantly more uterine luminal neutrophils in progesterone-treated than in oestradiol-treated mares by $24 \mathrm{~h}$ after infusion $(P<0.01)$. Uterine washings collected from progesterone-treated mares at 0 , 24 and $144 \mathrm{~h}$ were significantly worse at promoting bactericidal activity by neutrophils than washings from oestradiol-treated and control mares $(P<0.001)$. In oestrogentreated and control mares bactericidal activity had increased by $144 \mathrm{~h}$ but in progesterone-treated mares bactericidal activity remained low. Neither treatment nor time affected the ability of washings to opsonize yeast blastospores. Elevated concentrations of progesterone in plasma were therefore associated with decreased bactericidal activity of neutrophils suspended in uterine washings but the generation of $\mathrm{C}_{3 \mathrm{~b}}$ in washings did not appear to be affected by hormone treatment.
\end{abstract}

\section{Introduction}

Uterine infection in mares is one of the major causes of failure of conception (Bain, 1966) and the bacteria most commonly implicated in this subfertility are $\beta$-haemolytic streptococci (Hughes $\&$ Loy, 1975). In many species the uterus is more susceptible to uterine infection in the progesteronedominated luteal phase than in the oestrogen-dominated follicular phase of the oestrous cycle. This deficiency may relate to cellular factors within the uterus, such as mobilization of phagocytes and their efficiency at phagocytosis and intracellular killing, or to humoral factors which may be immunologically specific or non-specific.

The components in uterine secretions which promote bacterial killing have not been studied in detail. When present in sufficiently high concentrations, antibody directed against specific antigenic determinants on bacterial cell walls will opsonize the bacteria and aid phagocytosis by neutrophils (Stossel, 1974). This process is greatly enhanced, however, by activation of the classical or alternative complement pathways. Deposition of one of the components of the complement pathway, $\mathrm{C}_{3 \mathrm{~b}}$, has been shown to be necessary for phagocytosis of Streptococcus zooepidemicus by equine neutrophils (Asbury et al., 1984). Direct activation of the alternative pathway by $S$. zooepidemicus is suggested to be of little importance (Asbury et al., 1984), although another group C streptococcus, $S$. equi, is known to be a potent activator of the alternative pathway of complement (Mukhtar \& Timoney, 1985).

In the mare the clinical response to intrauterine infusion of bacteria was thought to be similar in oestrus and dioestrus (Peterson et al., 1969; Hughes \& Loy, 1975). More recent work has shown that infection persisted in progesterone-treated ovariectomized mares, suggesting an hormonal 
influence on the ability to eliminate bacteria from the uterus (Ganjam et al., 1982). In cattle the ability of uterine secretions to promote bactericidal activity is reduced during the luteal phase of the oestrous cycle (Watson, 1985). However, conflicting results have been obtained for mares when different methods have been used to assess phagocytosis and bactericidal activity of neutrophils suspended in uterine washings (Blue et al., 1982; Brown et al., 1985).

The present study investigated the efficacy of killing of Streptococcus zooepidemicus when neutrophils were suspended in uterine washings collected from hormone-treated ovariectomized mares after induction of an immunologically non-specific endometritis. Secondly, the efficiency of opsonization of yeast blastospores by uterine washings was studied to monitor any changes in complement-mediated opsonization which might be induced by ovarian steroids.

\section{Materials and Methods}

Animals and experimental design. Each of 4 ovariectomized Pony mares weighing $250-300 \mathrm{~kg}$ was treated on 3 separate occasions for 14 days with daily i.m. injections $(4 \mathrm{ml})$ of oestradiol benzoate $(0 \cdot 25 \mathrm{mg} / \mathrm{ml})$, progesterone $(25 \mathrm{mg} / \mathrm{ml})$ or the oily vehicle, arachis oil (Intervet, Cambridge, U.K.). On each occasion $(n=3)$ every mare $(\mathrm{N}=4)$ received different hormone treatments. This treatment regimen has been shown to induce changes in plasma hormones and in the histological morphology of the endometrium consistent with oestrus, dioestrus and anoestrus respectively (E. D. Watson, unpublished data).

On Day 8 of hormone treatment, uterine washings were collected via a Foley catheter ( $24 \mathrm{FG}, 30 \mathrm{ml}$ cuff) by flushing the uterus with $40 \mathrm{ml}$ sterile phosphate-buffered saline (PBS; $0 \cdot 1 \mathrm{M}, \mathrm{pH} \mathrm{7.0)}$ (Watson et al., 1987). Oyster glycogen $(1 \%)$ in $50 \mathrm{ml}$ sterile PBS was infused into the uterus before withdrawal of the catheter to induce an acute inflammatory response. This method of inducing acute endometritis has previously been described for cattle (Anderson et al., 1984; Watson, 1985) and mares (Watson et al., 1987). The washing procedure was repeated at 1, 3,6, 24 and $144 \mathrm{~h}$ after infusion.

Treatment of washings. Uterine washings were kept on ice until centrifuged at $125 \mathrm{~g}$ for $10 \mathrm{~min}$. Cells in the pellet were counted using a haemocytometer. Cell viability was determined by addition of trypan blue dye $(0 \cdot 1 \% ; 1: 1, \mathrm{v} / \mathrm{v})$ and calculation of the percentage of cells which excluded the dye. Differential cell counts were performed using a cytospin preparation (Dulin et al., 1982) stained with Giemsa dye (Diff-Quick, American Hospital Supplies, Compton, Berkshire, U.K.). The supernatant was further centrifuged at $10000 \mathrm{~g}$ for $30 \mathrm{~min}$, decanted into aliquants and frozen at $-70^{\circ} \mathrm{C}$. To detect the presence of aerobic bacteria in washings a drop of fluid from each flushing was streaked onto a blood agar plate and incubated at $37^{\circ} \mathrm{C}$ for $48 \mathrm{~h}$.

Bactericidal assay. This assay, along with isolation of blood neutrophils, was performed as described by Watson $e t$ al. (1987) using $0 \cdot 1 \mathrm{ml}$ Streptococcus zooepidemicus $\left(3 \times 10^{6} / \mathrm{ml}\right), 0.2 \mathrm{ml}$ neutrophils $\left(1 \times 10^{7} / \mathrm{ml}\right)$ collected from one gelding and $0.3 \mathrm{ml}$ uterine washing. All washings were sterilized by filtration before use $(0.45 \mu \mathrm{m}$ Millipore; Flow Laboratories, Irvine, U.K.). The tubes were prepared in duplicate and were rolled at $37^{\circ} \mathrm{C}$ for $2 \mathrm{~h}$. The numbers of viable colony forming units (c.f.u.) which remained at the end of the incubation were assessed by spotting $0.02 \mathrm{ml}$ drops of $3 \times 10$-fold dilutions in sterile saline onto blood agar plates. The survival of bacteria was calculated by: (no. of c.f.u. obtained with test uterine washings/no. of c.f.u. in duplicate tubes in which the neutrophils were replaced by $0.2 \mathrm{ml}$ Hank's Balanced Salt Solution (HBSS) and the uterine washings by $1 \%$ horse serum) $\times 100 \%$.

Control tubes were those in which uterine washings or neutrophils were replaced by PBS.

Yeast phagocytosis assay. This assay was performed as described by Soothill \& Harvey (1976) with minor modifications. Blood neutrophils were isolated as described by Watson et al. (1987) and $1 \times 10^{8}$ heat killed yeast blastospores $/ \mathrm{ml}(0.2 \mathrm{ml})$ were added to $0.1 \mathrm{ml}$ washing and $0.1 \mathrm{ml}$ neutrophils $\left(1 \times 10^{7} / \mathrm{ml}\right)$. Tubes were rolled for $45 \mathrm{~min}$ at $37^{\circ} \mathrm{C}$ and then centrifuged at $50 \mathrm{~g}$ for $5 \mathrm{~min}$. The sediment was resuspended in saline $(0.9 \%(\mathrm{w} / \mathrm{v}) \mathrm{NaCl}, 1.5 \mathrm{ml})$ and a cytospin preparation was stained with Giemsa. The number of yeast blastospores ingested by 100 neutrophils was counted and the phagocytotic index was expressed as blastospores/neutrophil.

Total protein assay. Total protein was measured in washings using a Lancer Microprotein Rapid Stat Diagnostic Kit (Clandon Scientific Ltd., Aldershot, U.K.). The method was based on formation of a dye-protein complex with Coomassie Brilliant Blue dye. Protein concentrations were assessed colorimetrically.

Statistical methods. The effects of horse and time on the variates were analysed by a blocked analysis of variance (with horse as the blocking factor) using a computer statistical package (Genstat, Rothamsted, U.K.). Relationships between measurements were analysed by the Pearson correlation coefficient test. Results were considered significant when $P<0.05$. All means are quoted \pm s.e.m.

\section{Results}

All washings were culturally negative for bacteria except at $144 \mathrm{~h}$ for 2 mares treated with progesterone. Bacteria isolated from 1 of these mares were Streptococcus zooepidemicus and from the other Staphylococcus aureus. 
In all statistical analyses the effect of horse was not significant.

Infusion of glycogen resulted in a large influx of neutrophils into the uterus by $24 \mathrm{~h}$ regardless of hormone treatment (Fig. 1). Progesterone treatment significantly increased numbers of intrauterine neutrophils at 24 and $144 \mathrm{~h}$ after infusion compared with the other two groups. The number of neutrophils in washings collected at 1,3 and $6 \mathrm{~h}$ after infusion of glycogen increased significantly with time $(P<0.01)$ but there was no significant difference among the three treatment groups in speed of mobilization of neutrophils into the uterine lumen (Table 1). When bacteria were

Table 1. Rate of mobilization of neutrophils into the uterine lumen of ovariectomized mares treated with ovarian steroids

\begin{tabular}{lcc}
\hline $\begin{array}{l}\text { Hormone } \\
\text { treatment }\end{array}$ & $\begin{array}{c}\text { Time after } \\
\text { infusion } \\
\text { (h) }\end{array}$ & $\begin{array}{c}\text { Mean }( \pm \text { s.e.m. }) \\
\text { no. of viable } \\
\text { neutrophils in } \\
\text { washing }\left(\log _{10}\right)\end{array}$ \\
\hline Oestrogen & 1 & $2 \cdot 0 \pm 0 \cdot 85$ \\
& 3 & $5 \cdot 9 \pm 0 \cdot 40$ \\
Progesterone & 6 & $7 \cdot 5 \pm 0 \cdot 41$ \\
& 1 & $4 \cdot 3 \pm 0 \cdot 30$ \\
Control & 3 & $5 \cdot 7 \pm 0 \cdot 25$ \\
& 6 & $8 \cdot 2 \pm 0 \cdot 11$ \\
& 1 & $2 \cdot 8 \pm 1 \cdot 65$ \\
& 3 & $6.0 \pm 0.40$ \\
& 6 & $7 \cdot 7 \pm 0 \cdot 21$ \\
\hline
\end{tabular}

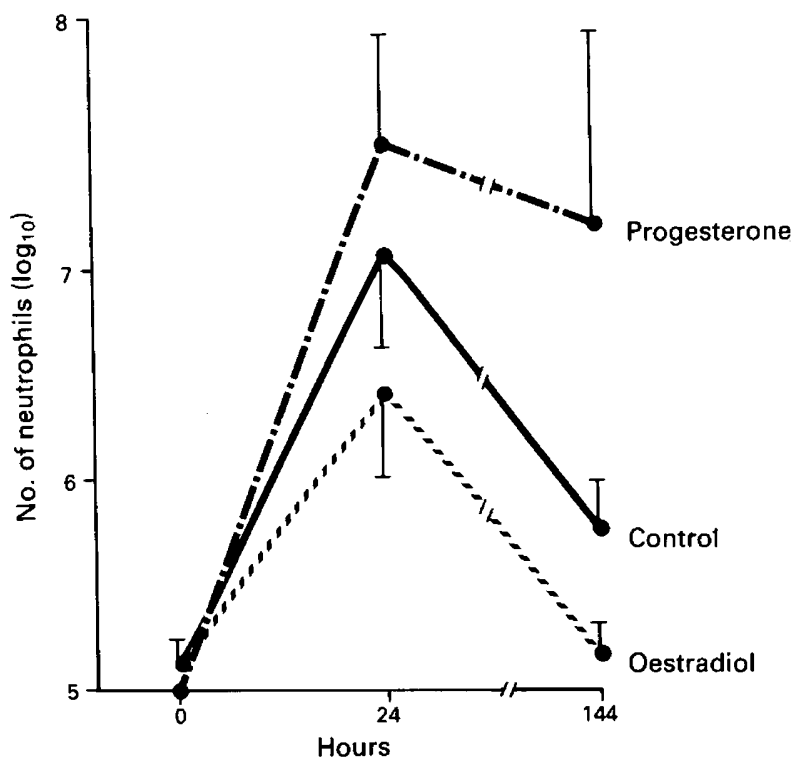

Fig. 1. Mean ( \pm s.e.m.) numbers of viable neutrophils in uterine washings collected after infusion of glycogen from mares treated with oestrogen, progesterone or arachis oil. At $24 \mathrm{~h}$ after infusion, neutrophil numbers were higher in washings from progesterone-treated than oestrogen-treated mares $(P<0.01)$. By $144 \mathrm{~h}$, progesterone-treated mares had more intraluminal neutrophils than either of the other groups $(P<0.001)$. 


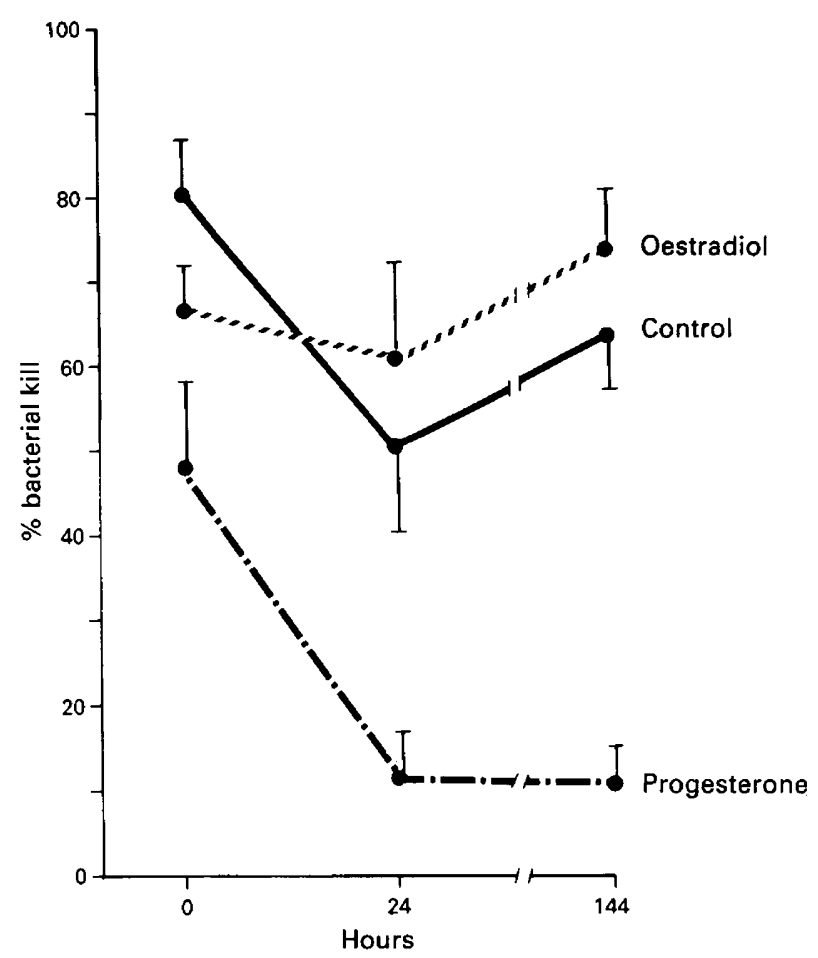

Fig. 2. Mean ( \pm s.e.m.) percentage kill of $S$. zooepidemicus by neutrophils suspended in uterine washings collected after infusion of glycogen from mares treated with oestrogen, progesterone or arachis oil. Overall, both time after infusion $(P<0.01)$ and hormone treatment $(P<0.001)$ had a significant effect on bactericidal activity of neutrophils. Before infusion, washings from progesterone-treated mares were significantly worse at promoting bactericidal activity than those from oestrogen-treated $(P<0.02)$ or control mares $(P<0.001)$. At both 24 and $144 \mathrm{~h}$ after infusion, bacterial kill was significantly lower $(P<0.001)$ with washings from progesterone-treated mares than from the other two groups.

Table 2. Phagocytosis of yeast opsonized by uterine washings from ovariectomized mares treated with ovarian steroids

\begin{tabular}{lccc}
\hline $\begin{array}{l}\text { Time of collection } \\
\text { of washings } \\
\text { after infusion }\end{array}$ & \multicolumn{3}{c}{ Number of yeast particles/neutrophil } \\
\cline { 2 - 4 } glycogen (h) & Oestrogen & Progesterone & Controls \\
\hline-0 & 0.800 & 0.850 & 0.600 \\
24 & 0.975 & 0.825 & 0.750 \\
48 & 1.300 & 0.975 & 1.150 \\
\hline
\end{tabular}

Hormone $\times$ time s.e.d. $=0.369$.

incubated with neutrophils in the absence of washings, $6 \%$ of bacteria were killed. Incubation of bacteria with 6 different uterine washings in the presence or absence of neutrophils resulted in a decrease in mean bacterial kill from 53 to $16 \%(P<0.02)$. Neutrophils suspended in uterine washings from mares treated with progesterone were significantly worse at killing bacteria than those from oestrogen-treated or control mares (Fig. 2). 
The number of yeast blastospores ingested by neutrophils after opsonization in uterine washings was significantly greater $(P<0.001)$ than after substitution of washings by PBS $(0.23 \pm 0.05 /$ neutrophil). Neither treatment nor time of collection of washings influenced the ability of washings to opsonize yeast particles (Table 2).

Before infusion of glycogen, there was no significant difference in protein concentrations between mares treated with progesterone $(100 \pm 60 \mu \mathrm{g} / \mathrm{ml})$, oestradiol $(51 \pm 22 \mu \mathrm{g} / \mathrm{ml})$ or controls $(40 \pm 19 \mu \mathrm{g} / \mathrm{ml})$. Overall, however, mean protein concentrations were higher $(P<0.001)$ in uterine washings from progesterone-treated mares $(587 \pm 196 \mu \mathrm{g} / \mathrm{ml})$ than in oestrogen-treated mares $(63 \pm 15 \mu \mathrm{g} / \mathrm{ml})$. Protein concentrations in control mares $(207 \pm 134 \mu \mathrm{g} / \mathrm{ml})$ were not statistically different from those in progesterone-treated mares.

The percentage kill of bacteria in vitro was inversely related both to the protein concentration of the uterine washings $(r=-0.502 ; P<0.01)$ and to the number of neutrophils originally present in the washing $(r=-0.484 ; P<0.01)$. The number of neutrophils present in washings was directly correlated with the protein concentration of the washing $(r=0.834 ; P<0.001)$. Opsonization of yeast blastospores by uterine washings was not related to number of neutrophils originally present in the washing, percentage bacterial kill or protein concentration of the washings.

\section{Discussion}

Opsonization is required for phagocytosis of Streptococcus zooepidemicus by horse neutrophils (Asbury et al., 1982). Little is known of the process of opsonization of bacteria by factors present in uterine secretions, but since inactivation of complement in uterine secretions almost abolishes phagocytosis it would appear that deposition of $\mathrm{C}_{3 \mathrm{~b}}$ on the bacterial cell wall may have an important role (Asbury et al., 1984). In the present study phagoctyosis of yeast blastospores was used to assess changes in the deposition of $\mathrm{C}_{3}$ fragments in uterine secretions from mares treated with oestradiol or progesterone. In the absence of specific antibody, yeasts will activate complement via the alternative complement pathway (Soothill \& Harvey, 1976). It has been suggested, however, that in some cases antibody may be present which permits the classical pathway of complement to contribute to $\mathrm{C}_{3 \mathrm{~b}}$ generation (Turner et al., 1985). In uterine washings the relative importance of this contribution remains to be determined. Impaired phagocytosis of yeast blastospores after opsonization with human serum has been used to detect defects in the alternative pathway of complement activation and deposition of $\mathrm{C}_{3}$ fragments (Soothill \& Harvey, 1976; Turner et al., 1986). Uterine washings were capable of significantly enhancing phagocytosis compared with PBS and $\mathrm{C}_{3 \mathrm{~b}}$ could therefore be generated in uterine secretions. Other workers have suggested that although $S$. zooepidemicus did not seem to activate the alternative pathway of complement directly, this pathway is likely to play a role in opsonization of gram-negative bacteria (Asbury et al., 1984).

The results of the present study showed that neither hormone treatment nor induction of acute endometritis affected the generation and deposition of complement fragments in washings on to yeast blastospores. This finding contrasted with results from cattle and rabbits; washings from luteal-phase animals contained a seromucoid component which inhibited phagocytosis of starch particles (Killingbeck \& Lamming, 1963).

The killing of bacteria by neutrophils in the presence of uterine washings collected before infusion of glycogen was high in oestrogen-treated and control mares but was significantly depressed in mares treated with progesterone. Brown et al. (1985) used chemiluminescence to study bacterial phagocytosis and reported very low light emission when bacteria were opsonized with washings from uninfected mares in oestrus and dioestrus. This apparent contradiction may be due to the different techniques used to study opsonization. In the present study non-specific bactericidal substances present in washings may have contributed to the results.

After induction of acute endometritis, bacterial kill by neutrophils decreased markedly when suspended in washings from progesterone-treated mares and remained low until the end of the 
experiment when 2 of the 4 progesterone-treated mares succumbed to uterine infection. The failure to demonstrate any suppression of yeast phagocytosis by neutrophils suspended in washings from progesterone-treated mares would suggest that it is unlikely that factors present in washings had a direct effect on neutrophil phagocytosis. However, the uterine washings may have modified the bactericidal activity of neutrophils in addition to their role as bacterial opsonins.

In uterine washings from normal mares, IgG levels relative to total protein were apparently depressed during dioestrus (Widders et al., 1985). The reduced availability of this immunoglobulin when plasma concentrations of progesterone were high may have contributed to the decreased opsonization by washings. Alternatively, the large numbers of neutrophils in washings from progesterone-treated mares may have caused breakdown of immunoglobulins by release of neutrophil proteases (Waller, 1974) which would explain the significant negative correlation between numbers of neutrophils present in washings and opsonizing ability of the washings.

Uterine neutrophils may have a phagocytic function which is greater than or similar to that of blood neutrophils depending on the method of stimulating an acute endometritis (Targowski et al., 1985). It is likely that uterine neutrophils collected in the presence of bacterial infection are already activated whereas the circulating neutrophils used in this study were presumably unstimulated at the time of collection. It would therefore be interesting to extend the present study to investigate the interaction between uterine neutrophils and washings.

Killing of bacteria by neutrophils was inversely related to the protein concentration of the opsonizing washing. However, when uterine fluids were diluted so that the protein concentration was equivalent in all samples, bacterial killing did not change significantly and remained significantly correlated with washings which were not corrected for protein concentration $(n=11$; $r=0.688 ; P<0.02$ ).

Previous work showed that only during dioestrus did uterine fluid from mares inhibit growth of Streptococcus zooepidemicus in the absence of neutrophils (Strzemienski et al., 1984). In the present study there was little evidence of significant bacterial killing in the absence of neutrophils, but further work is needed to elucidate the role of bactericidal proteins in uterine washings from hormone-treated ovariectomized mares. Bactericidal proteins such as lactoferrin (Dixon \& Gibbons, 1979), lysozyme (Roberts et al., 1976) and peroxidase (Linford, 1974) have been isolated from uterine fluid of other species. Peroxidase has been measured in uterine washings from mares but was present in very low concentrations in uninfected uteri and was not correlated with stage of oestrous cycle (Blue et al., 1982). In the present study the bacterial kill was inversely related to the number of neutrophils originally present in the washing. The increased concentrations of peroxidase which are associated with the presence of high numbers of neutrophils (Linford, 1974) must therefore have had a negligible effect on bacterial killing due to other overriding factors present in the progesterone-treated mares.

In the present study hormone treatment did not affect speed of mobilization of neutrophils in the first $6 \mathrm{~h}$ after infusion, although in other species high plasma concentrations of progesterone have been shown to delay intrauterine migration of neutrophils (Broome et al., 1960; Hawk et al., 1961). Delayed neutrophil mobilization in the mare is therefore not the explanation of the increased susceptibility to infection in the progesterone-treated mares and, by $24 \mathrm{~h}$ after infusion, the progesterone-treated mares had significantly more uterine luminal neutrophils than did the other groups.

In conclusion, progesterone administration did not affect mobilization of neutrophils into the uterine lumen or the generation of $\mathrm{C}_{3 b}$ in uterine washings. However, the ability of washings to promote bactericidal activity by neutrophils was significantly reduced in these mares, which may be an important factor in increasing the susceptibility of dioestrous mares to intrauterine infection.

This study was supported financially by the Horserace Betting Levy Board. We thank Professor $H$. Pearson for performing the experimental surgery. 


\section{References}

Anderson, K.L., Hemeida, N.A., Frank, A., Gustafsson, B.K. \& Whitmore, H.L. (1984) Effect of oyster glycogen on number of neutrophils recovered from the bovine uterus. Proc. 10th Int. Congr. Anim. Reprod. \& A.I., Urbana-Champaign Vol. III, 442, Abstr.

Asbury, A.C., Schultz, K.T., Klesius, P.H., Foster, G.W. \& Washburn, S.M. (1982) Factors affecting phagocytosis of bacteria by neutrophils in the mare's uterus. J. Reprod. Fert., Suppl. 32, 151-159.

Asbury, A.C., Gorman, N.T. \& Foster, G.W. (1984) Uterine defense mechanisms in the mare: serum opsonins affecting phagocytosis of Streptococcus zooepidemicus by equine neutrophils. Theriogenology 21, 375-383.

Bain, M.A. (1966) The role of infection in infertility in the Thoroughbred mare. Vet. Rec. 78, 168-173.

Blue, M.G., Brady, A.A., Davidson, J.N. \& Kenney, R.M. (1982) Studies on the composition and antibacterial activity of uterine fluid from mares. J. Reprod. Fert., Suppl. 32, 143-149.

Broome, A.W., Winter, A.J., McNutt, S.H. \& Casida, L.E. (1960) Variation in uterine response to experimental infection due to the hormonal state of the ovaries II Mobilisation of leucocytes and their importance in uterine bactericidal activity. $A m$. J. vet. Res. 21, 675-682.

Brown, A.E., Hansen, P.J. \& Asbury, A.C. (1985) Induction of opsonins in uterine flushings of cyclic mares by intrauterine inoculation of Streptococcus. Am. J. Reprod. Immunol. Microbiol. 7, Abstr. 23.

Dixon, S.N. \& Gibbons, R.A. (1979) Proteins in the uterine secretions of the cow. J. Reprod. Fert. 56, $119-127$.

Dulin, A.M., Paape, M.J. \& Weinland, B.T. (1982) Cytospin centrifuge in differential counts of milk somatic cells. J. Dairy Sci. 65, 1247-1251.

Ganjam, V.K., McLeod, C., Klesius, P.H., Washburn, S.M., Kwapien, R., Brown, B. \& Fazeli, M.H. (1982) Effect of ovarian hormones on the phagocytic response of ovariectomized mares. J. Reprod. Fert., Suppl. 32, 169-174.

Hawk, H.W., Turner, G.D. \& Sykes, J.F. (1961) Variation in the inflammatory response and bactericidal activity of the sheep uterus during the estrous cycle. Am. J. vet. Res. 21, 689-692.

Hughes, J.P. \& Loy, R.G. (1975) The relation of infection to infertility in the mare and stallion. Equine vet. J. 7, 155-159.

Killingbeck, J. \& Lamming, G.E. (1963) Influence of uterine secretions on phagocytosis. Nature, Lond. 198, $111-112$.
Linford, E. (1974) Cervical mucus: an agent or a barrier to conception. J. Reprod. Fert. 37, 239-250.

Mukhtar, M.M. \& Timoney, J.F. (1985) Chemotactic response of equine polymorphonuclear leucocytes to Streptococcus equi. Proc. 66th Ann. Conf. Res. Workers Anim. Dis., Chicago, Abstr. 331.

Peterson, F.B., McFeely, R.A. \& David, J.S.E. (1969) Studies on the pathogenesis of endometritis in the mare. Proc. 15th Ann. Conf. Am. Assoc. Equine Pract. Houston 279-287.

Roberts, R.M., Bazer, F.W., Baldwin, N. \& Pollard, W.E. (1976) Progesterone induction of lysozyme and peptidase activities in the porcine uterus. Archs Biochem. Biophys. 177, 499-507.

Soothill, J.F. \& Harvey B.A.M. (1976) Defective Opsonization-a common immunity deficiency. Arch. Dis. Child. 51, 91-99.

Stossel, T.P. (1974) Phagocytosis. New Engl. J. Med. 290, 717-723.

Strzemienski, P.J., Do, D. \& Kenney, R.M. (1984) Antibacterial activity of mare uterine fluid. Biol. Reprod. 31, 303-311.

Targowski, S.P., Hartman, G. \& Warner, D.P. (1985) Activation of phagocytic leukocytes in the uterus. Am. J. Reprod. Imm. Microbiol. 7, Abstr. 19.

Turner, M.W., Seymour, N.D., Kazatchkine, M.D. \& Mowbray, J.F. (1985) Suboptimal $C_{3 b} / C_{3 b i}$ deposition and defective yeast opsonization. I. Evidence for the absence of essential co-factor activity. Clin. exp. Immunol. 62, 427-434.

Turner, M.W., Grant, C., Seymour, N.D., Harvey, B. \& Levinsky, R.J. (1986) Evaluation of $\mathrm{C}_{3 b} / \mathrm{C}_{3 \mathrm{bi}}$ opsonization and chemiluminescence with selected yeasts and bacteria using sera of different opsonic potential. Immunology 58, 111-115.

Waller, M. (1974) IgG hydrolysis in abscesses 1. A study of the IgG in abscess fluid. Immunology 26, 725-733.

Watson, E.D. (1985) Opsonising ability of bovine uterine secretions during the oestrous cycle. Vet. Rec. 117, 274-275.

Watson, E.D., Ricketts, S.W., Stokes, C.R., David, J.S.E. \& Bourne, F.J. (1987) Concentrations of uterine luminal prostaglandins in mares with acute and persistent endometritis. Eq. vet. $J$. (in press).

Widders, P.R., Stokes C.R., David, J.S.E. \& Bourne, F.J. (1985) Effect of cycle stage on immunoglobulin concentrations in reproductive tract secretions of the mare. J. Reprod. Immunol. 7, 233-242.

Received 7 July 1986 